Clarifying the Meaning of Symbolic Racism

\author{
Joshua D. Wright \\ St. Joseph's College \\ Zach Goldberg \\ Georgia State University
}

Irene Cheung

Huron University College, University of Western Ontario

Victoria M. Esses

University of Western Ontario

This version is a preprint. It has not gone through the process of peer review. We welcome any feedback on this version of the manuscript.

Data collection for Study $1 \& 2$ was funded through a grant from the Social Sciences and Humanities Research Council of Canada (SSHRC) to the fourth author. Study 3 was funded through an internal grant to the third author from Huron University College, University of Western Ontario. Studies 4-6 used openly available data.

Open materials for this paper can be found here: https://osf.io/hg86q/

Correspondence concerning this article should be addressed to Joshua D. Wright, St. Joseph's College, Patchogue, NY. Email: jwright6@sjcny.edu 


\begin{abstract}
We examined whether symbolic racism is associated with anti-Black affect or more general antiliberal affect. Across six studies $(N=14,078)$, we determined that symbolic racism is associated with more positive attitudes toward conservatives and more negative attitudes toward liberals, regardless of the target's race. While high scorers on the symbolic racism scale show a slight preference for White vs. Black conservatives $(d=.15)$ and White vs. Black liberals $(d=.12)$, low scorers show a considerable preference for Black vs. White liberals $(d=.42)$ and Black vs. White conservatives $(d=.50)$. Lingering questions about the validity of the symbolic racism construct are justified on the basis that symbolic racism does not reliably measure anti-Black affect.
\end{abstract}

Keywords: symbolic racism, modern racism, racial resentment, prejudice 


\section{Clarifying the Meaning of Symbolic Racism}

Racism was once clearly defined in the United States. It represented a belief in White supremacy, Black inferiority, and a desire for racial segregation (Sniderman \& Tetlock, 1986a). This was reflected in public opinion polls. In 1942, 84\% of Americans thought there should be separate sections in towns and cities for Blacks to live and $31 \%$ did not think employers should hire Blacks at all (Allport, 1958). Likewise, in 1946, 46\% of Americans thought Whites should have the first chance at any kind of job (Allport, 1958). The 1970's saw a leap forward in racial tolerance (Taylor et al., 1978). This progress led some scholars to claim that the White supremacist and segregationist form of racism had declined to such an extent that America had become, in principle, racially egalitarian (Kinder \& Sears, 1981). For some racial prejudice researchers this decline in overt racism did not mean that racism had truly declined; rather, a new form of racism had supplanted the old one. This new form took the name symbolic racism (Henry \& Sears, 2002; Kinder \& Sears, 1981; McConahay \& Hough Jr, 1976), modern racism (McConahay, 1983; McConahay et al., 1981), and racial resentment (Kinder \& Sanders, 1996). While described in somewhat different terms, the corresponding scales for these constructs use the same, or similar content. For example, all three scales measure the belief that Blacks get more than they deserve. Both the symbolic racism (Henry \& Sears, 2002) and racial resentment (Kinder \& Sanders, 1996) scales use the same exact item ("Over the past few years, blacks have gotten less than they deserve," reverse scored) and the modern racism scale (McConahay, 1983) uses a slight variation ("Over the past few years, blacks have gotten more economically than they deserve"). All of these constructs also share emphasis on perceptions of discrimination. The symbolic racism and racial resentment scales include "Generations of slavery and discrimination have created conditions that make it difficult for Blacks to work their way out of the lower class" 
(reverse scored), while the modern racism scale uses, "Discrimination against blacks is no longer a problem in the United States". Importantly, even though the measures have three different names, they are all measuring the same underlying construct because they use the same, or very similar, items. For simplicity, we will refer to this construct as symbolic racism throughout. Symbolic racism was defined as, "a blend of antiblack affect and the kind of traditional American values embodied in the Protestant Ethic", which includes "individualism and selfreliance, the work ethic, obedience, and discipline" (Kinder \& Sears, 1981, p. 416). This blending of conservative political content into the symbolic racism construct has been criticized. Sniderman and Tetlock (1986a) argued that the theoretical construct defines opposition to political policies as inherently racist, regardless of individuals' motivations for policy preferences. For example, opposition to university quotas for minority admissions was incorporated as an early symbolic racism item (Kinder \& Sears, 1981), although this form of affirmative action had already been struck down by the United States Supreme Court in 1978. Other race-related policies could be framed as racist if they were connected to conservative political values (Sniderman \& Tetlock, 1986a; 1986b). As Sniderman and Tetlock (1986b) suggest, the symbolic racism approach requires that "Racists... are by definition conservatives; and conservatives, again by definition, are racists" (p. 181). As pointed out by Schuman (2000) and reiterated by Carmines et al. (2011), some of the evidence supporting the validity of the construct is based upon tautologies, in which symbolic racism is used to predict racial policies that essentially reflect the content of a symbolic racism item. For example, the symbolic racism item, "Over the past few years, blacks have gotten less than they deserve" and the policy preference item "Should Federal spending on programs that assist blacks be increased, decreased, or kept about the same?" are tautological but used to imply convergent validity for 
symbolic racism in Kinder and Sanders (1996). Both appear to reflect the same underlying attitude and factor analyses on seven nationally representative datasets suggest that the symbolic racism items and racial policy preference items reflect the same underlying construct, rather than the two distinct constructs of symbolic racism and policy preferences respectively (Carmines et al., 2011).

For close to 40 years, symbolic racism has been the focal construct for understanding racial attitudes in the United States (Biernat \& Crandall, 1999; Carney \& Enos, 2017; Tesler, 2012) and its corresponding measures have been used to make claims of racial motivations for opposition to affirmative action (Matsueda \& Drakulich, 2009; Sears et al., 1997), opposition to universal healthcare (Maxwell \& Shields, 2014), support for the Confederate battle flag (Cooper \& Knotts, 2006; Orey, 2004), opposition to Barack Obama (Ditonto, Lau, \& Sears, 2013; Payne et al., 2010), support for Donald Trump (al Gharbi, 2018; Tien, 2017), support for punitive crime policies (Green et al., 2006), and other race-relevant outcome variables (Carney \& Enos, 2017; Henry \& Sears, 2002; Kinder \& Sears, 1981; Sears et al., 1997; Sniderman \& Tetlock, 1986a). Since at least 1988, symbolic racism has been associated with a preference for Republican presidential candidates (Abramowitz \& McCoy, 2019).

The symbolic racism construct shows stronger associations with political ideology than anti-Black affect (Ditonto et al., 2013). Thus, conservative values may better explain racetargeted policy opinions than reflecting racial attitudes per se (Feldman \& Huddy, 2005; Zigerell, 2015). Moreover, in some cases, adherence to traditional values is associated with entitling Blacks to more, not less, government assistance (Sniderman et al., 1991). Additionally, symbolic racism among Black respondents is associated with opposition to policies designed to assist Blacks (Zigerell, 2015), and symbolic racism predicts non-racial outcome variables such as 
opposition to gays serving in the military (Kinder \& Sanders, 1996), opposition to EPA regulation of $\mathrm{CO}_{2}$ emissions (Zigerell, 2019), and opposition to gun control legislation (O'Brien et al., 2013).

As Zigerell (2015) indicates, items such as "It's really a matter of some people not trying hard enough; if blacks would only try harder they could be just as well off as whites"1 cannot identify racial attitudes "because a person who agreed with the statement might also agree that poor whites who try harder could be just as well off as middle-class whites" (p. 2). Presciently, this is precisely what occurs (Carney \& Enos, 2017). If symbolic racism were to measure antiBlack affect, respondents should report the highest scores on symbolic racism measures when Blacks are the target group represented within the item. Instead, symbolic racism scores are highest when Whites are the target group represented within the item and lowest when Blacks are the target group (Carney \& Enos, 2017). This appears to be driven by liberals showing increased racial sympathy toward Blacks relative to Whites. Conservatives, on the other hand, respond consistently across target groups. Indeed, conservatives appear to resent all targets equally because, in general, they resent those who get more than they deserve, require special favors to succeed, or don't work hard - all of which contradict the protestant work ethic (Carney and Enos, 2017). In short, liberals, not conservatives, inconsistently apply their resentment toward those who get more than they deserve, require special favors to succeed, or don't work hard based upon racial group, while conservatives consistently apply the resentment regardless of racial group. Thus, symbolic racism scores appear to reflect more general attitudes about work ethic and fairness (i.e., getting what you work for) than anti-Black affect.

1 This item is contained within both the symbolic racism and racial resentment scales. 
Chambers et al. (2013) had participants rate their impression of either an African American target or a European American target who held either a conservative or liberal attitude position (e.g., a European American who favored welfare). Impressions of these crossed ethnicideological targets were correlated with a measure of symbolic racism (McConahay, 1986), which indicated that regardless of racial background, symbolic racism was strongly associated with positive impressions of conservative targets and negative impressions of liberal targets. If symbolic racism measures racial attitudes it should generally track attitudes toward the target racial group (e.g., African Americans), not track political groups regardless of race.

The typical use of the symbolic racism measures follows the "residual racism" assumption. Under the "residual racism" assumption, after statistically controlling for conservatism, any remaining association between a measure of symbolic racism and the dependent variable of interest is a product of racial prejudice (Pasek et al., 2009). This interpretation assumes that $100 \%$ of the variance in a battery of items assessing conservatism is accounted for by the latent construct of conservatism - that is, that there is no systematic or unsystematic error in measurement. This is an unreasonable assumption. Even after extensive controls for conservatism, remaining variance in an outcome still associated with the symbolic racism scale could reflect various aspects of conservatism not already accounted for, or could reflect random noise. If we assume that associations between symbolic racism and non-racial outcome variables are zero (e.g., support for increased defense spending) then the residual effects of symbolic racism on non-racial outcomes after controlling for conservatism can be used to estimate the lower bound of effect size that would be reasonably assumed to reflect anti-Black bias, rather than random noise (Zigerell 2015). For example, if after controlling for Conservatism, the effect of symbolic racism on support for decreasing spending the poor were 
lower than the aggregated effect of symbolic racism on non-racial dependent variables, then attributing this effect to anti-Black bias would not be warranted. Zigerell (2015) demonstrates that after extensive controls for the conservative component of symbolic racism, many associations between symbolic racism and race-relevant outcome variables are reduced to the level of noise, including support for increased Federal spending to fight crime, decreased Federal spending on the poor, and disapproval of Barack Obama's performance. Moreover, after using the same extensive controls for conservatism, symbolic racism still predicted Black opposition to policies designed to help Blacks. This is inconsistent with the claim that the residual effects of symbolic racism are due to anti-Black affect. A plethora of studies do not make any attempt to extensively control for conservatism beyond a single ideological self-placement item or a categorical party identification item (e.g., Bobo \& Johnson, 2004; Ditonto, 2020; Sidanius et al., 1992), which are undoubtedly not adequate in order to make inferences about the effect of antiblack attitudes on policy opinions (Zigerell, 2015).

Despite over 40 years of criticism of the symbolic racism construct, it still remains the most widely used explicit racism measure (Carney \& Enos, 2017). This widespread use makes it important that it measures what it intends to measure. Through six studies, we evaluate whether symbolic racism is primarily associated with attitudes regarding race or attitudes regarding political orientation. If symbolic racism measures a more general and conservative attitude regarding work ethic and fairness, as indicated by Carney and Enos (2017), then the association between symbolic racism and attitudinal targets should follow a predictable pattern whereby symbolic racism is consistently associated with more negative attitudes toward liberals and more positive attitudes toward conservatives regardless of race, but not with more negative attitudes toward Blacks and more positive attitudes toward Whites, regardless of target political 
orientation. In contrast, if symbolic racism measures anti-Black affect (Kinder \& Sears, 1981), then the association between symbolic racism and attitudinal targets should follow a predictable pattern whereby symbolic racism is consistently associated with more negative attitudes toward Blacks and more positive attitudes toward Whites regardless of target ideology. Additionally, it is instructive to examine the extent to which strong symbolic racists hold differential attitudes towards White versus Black conservatives and White versus Black liberals, and to what extent those with low scores on symbolic racism hold differential attitudes towards White versus Black liberals and White versus Black conservatives. This will uncover whether the association between symbolic racism and attitudinal targets is a product of the high (symbolic racists) or the low (racial sympathizers) end of the scale.

\section{Study 1}

In Study 1, we examine whether we can replicate the reported patterns in Chambers et al. (2013), in which symbolic racism toward Blacks was associated with more negative impressions of both African American and European American liberal targets and was associated with more positive impressions of both African American and European American conservative targets. Our approach differs in two ways. First, we use the more explicit racial terms of "Black" and "White" rather than "African-American" and "European American", which reflect cultural heritage rather than skin color. Second, we pair race with explicit ideologies ("conservative" and "liberal") rather than using political positions on polarizing topics (e.g., affirmative action). This avoids any ambiguity as to the general political orientation of a target.

\section{Method}

We analyzed data from 559 White Southerners recruited from Mechanical Turk using the TurkPrime platform (Litman et al., 2017). These participants were recruited for another study 
(see Wright et al., 2020), and predominantly resided in Georgia $(N=258)$, South Carolina $(N=$ 106), Mississippi $(N=78)$, Alabama $(N=60)$, and Louisiana $(N=41)$. The sample included 175 males, 382 females, and 2 who identified as transgender. Ages ranged from 18 to $80(M=38.34$, $S D=12.03$ ). Participants completed a single item measure of political ideology ranging from 1

(very liberal) to 7 (very conservative). Participants then completed the 8-item SR-2000 (Henry \& Sears, 2002) on a scale from 1 to 5, as a measure of symbolic racism toward Blacks. After reverse coding relevant items, we computed mean scores, with higher scores indicating more symbolic racism $(\alpha=.90)$. Additionally, participants completed attitude thermometers toward "White liberals", "Black liberals", "White conservatives", and "Black conservatives", with scores ranging from 0 (negative) to 100 (positive). These attitude thermometers were presented in a random order following the completion of the SR-2000.

\section{Results and Discussion}

Descriptive statistics are reported in Table 1. The first frame of Figure 1 plots the relationship between target thermometer ratings and symbolic racism. Symbolic racism was associated with more positive attitudes toward White conservatives $(r=.59,95 \% \mathrm{CI}: .52, .65)$, more positive attitudes toward Black conservatives $(r=.47,95 \% \mathrm{CI}: .39, .54)$, more negative attitudes toward White liberals $(r=-.57,95 \% \mathrm{CI}:-.63,-.50)$, and more negative attitudes toward Black liberals ( $r=-.63,95 \% \mathrm{CI}:-.68,-.56)$.

Symbolic racism was more strongly associated with more positive attitudes toward White versus Black conservatives $(p=.005)$, but not more strongly associated with less positive attitudes toward Black versus White liberals $(p=.12)$. The former is a feature of two effects (see panel 1 in Figure 1). First, those with scores greater than one standard deviation above the mean on symbolic racism report more positive attitudes toward White conservatives $(M=78.73, S D=$ 
23.23) relative to Black conservatives $(M=72.45, S D=28.84), t(99)=3.25, p=.002, d=.33$.

Second, those with scores one standard deviation below the mean on symbolic racism report more positive attitudes toward Black conservatives $(M=29.95, S D=24.78)$ relative to White conservatives $(M=22.15, S D=23.53), t(95)=4.62, p<.001, d=.47$. That White Southerners high in symbolic racism express more positive attitudes toward White conservatives versus Black conservatives is consistent with the classic ingroup bias effect, in which individuals show favoritism toward ingroup members (Tajfel, 1970). In contrast, that White Southerners low in symbolic racism are more positive toward Black versus White liberals is inconsistent with the ingroup favoritism principle but is consistent with demonstrated racial sympathy toward Blacks among White liberals (Carney \& Enos, 2017), and with White liberals being more motivated to avoid appearing prejudiced (Wright \& Esses, 2017; Wright et al., 2020).

Those scoring high in symbolic racism do not report less positive attitudes toward Black liberals $(M=24.69, S D=26.42)$ relative to White liberals $(M=25.35, S D=25.86), t(99)=0.44$, $p=.66, d=.03$. However, those scoring low on symbolic racism do show relatively more positive attitudes toward Black liberals $(M=81.64, S D=20.04)$ relative to White liberals $(M=$ $78.68, S D=20.11), t(95)=3.07, p=.003, d=.31$. Importantly, those who score high in symbolic racism show considerable positivity toward both Black and White conservatives, while those who score low on symbolic racism show considerably less positive attitudes toward both Black and White conservatives, consistent with symbolic racism reflecting conservatism rather than anti-Black affect.

Table 1.

Descriptive statistics and correlations for Study 1 and Study 2

$\begin{array}{llllllll}1 & 2 & 3 & 4 & 5 & 6 & 7 & 8\end{array}$




\begin{tabular}{lcccccccc}
\hline 1. Conservatism & & .62 & .67 & .59 & -.68 & -.69 & .58 & -.67 \\
2. Symbolic Racism & .66 & & .57 & .43 & -.51 & -.64 & .44 & -.58 \\
3. White Conservatives & .70 & .59 & & .85 & -.40 & -.47 & .84 & -.45 \\
4. Black Conservatives & .64 & .47 & .88 & & -.37 & -.34 & .89 & -.34 \\
5. White Liberals & -.65 & -.57 & -.47 & -.43 & & .88 & -.35 & .87 \\
6. Black Liberals & -.65 & -.63 & -.51 & -.41 & .89 & & -.35 & .94 \\
7. Hispanic Conservatives & & & & & & & & -.30 \\
8. Hispanic Liberals & & & & & & & &
\end{tabular}

\section{Study 1}

$\begin{array}{lllllll}\text { Mean } & 4.07 & 2.89 & 53.50 & 56.11 & 52.90 & 53.02 \\ S D & 1.77 & .95 & 31.54 & 29.93 & 30.14 & 30.19\end{array}$

Study 2

$\begin{array}{lllllllll}\text { Mean } & 3.45 & 3.36 & 45.81 & 50.89 & 61.64 & 63.26 & 50.32 & 63.20 \\ S D & 1.75 & 1.75 & 33.54 & 31.08 & 29.54 & 30.38 & 30.41 & 29.65\end{array}$

Note: Correlations below the diagonal are from Study 1 and correlations above the diagonal are from Study 2. 


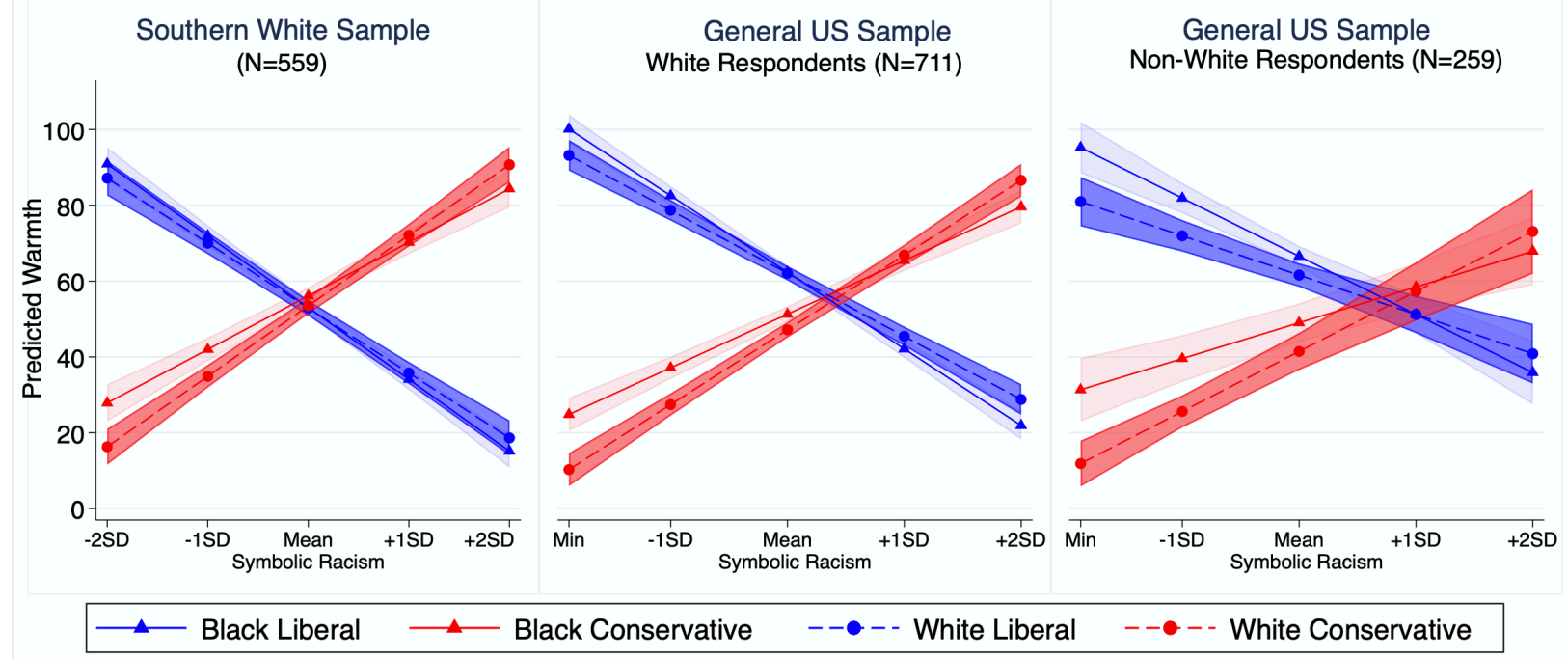

Figure 1. Relationships between symbolic racism and attitudes toward Black liberals, White liberals, Black conservatives, and White conservatives with $95 \%$ confidence intervals. Panel 1 reflects data from Study 1. Panels 2 and 3 reflect data from Study 2.

\section{Study 2}

In Study 2, we examine whether the associations in Study 1 will replicate in a broader sample of the U.S. population. Additionally, we added a third racial category to further test whether symbolic racism predicts attitudes toward targets based upon their political ideology regardless of race.

\section{Method}

We recruited 971 U.S. participants from TurkPrime (Litman et al., 2017). ${ }^{2}$ Participants included 448 males, 509 females, 12 who identified as transgender, and 2 that specified an alternative identity. Participants were highly educated, with 54.8\% holding at least a bachelor's

${ }^{2}$ We originally recruited 1005 participants. We removed 33 respondents for failing an attention check question and removed one individual who did not complete any of the attitude thermometers. 
degree, and age of the sample ranged from 18 to $78(M=38.10, S D=12.72)$. Following demographic questions, participants completed the same symbolic racism scale from Study 1, except that the scale was measured from 1 to $7(\alpha=.85)$. Then participants completed attitude thermometers toward "White liberals", "Black liberals", "Hispanic liberals", "White conservatives", "Black conservatives," and "Hispanic conservatives", with scores ranging from 0 (negative) to 100 (positive). These attitude thermometers were presented in a random order following the completion of the SR-2000.

\section{Results and Discussion}

Descriptive statistics are shown in Table 1. Symbolic racism was associated with more positive attitudes toward White conservatives $(r=.57,95 \% \mathrm{CI}: .52, .62)$, Black conservatives $(r$ $=.42,95 \% \mathrm{CI}: .37, .48)$, and Hispanic conservatives $(r=.44,95 \% \mathrm{CI}: .38, .50)$. Symbolic racism was also associated with more negative attitudes toward White liberals $(r=-.51,95 \% \mathrm{CI}:-.56$, -.46), Black liberals $(r=-.64,95 \%$ CI: -.67, -.59), and Hispanic liberals $(r=-.58,95 \%$ CI: -.62, -.54). There was a stronger correlation between symbolic racism and attitudes toward White versus Black conservatives $(p<.001)$ and a stronger relationship between symbolic racism and attitudes toward White versus Hispanic conservatives $(p<.001)$.

Consistent with Study 1, these differences are a feature of two effects (see panels 2 and 3 from Figure 1). First, those with scores greater than one standard deviation above the mean on symbolic racism reported more positive attitudes toward White conservatives $(M=73.81, S D=$ 27.34) relative to Black conservatives $(M=69.87, S D=27.82), t(159)=2.59, p=.01, d=.21$. They also reported more positive attitudes toward White conservatives relative to Hispanic conservatives $(M=70.61, S D=26.87), t(159)=2.28, p=.02, d=.18$. Second, those with scores one standard deviation below the mean on symbolic racism reported more positive attitudes 
toward Black conservatives $(M=31.94, S D=30.41)$ relative to White conservatives $(M=19.02$, $S D=25.90), t(174)=8.68, p<.001, d=.66$. They also reported more positive attitudes toward Hispanic conservatives $(M=31.70, S D=29.41), t(174)=9.11, p<.001, d=.69$, relative to White conservatives (See Figure 2).

Panels 2 and 3 from Figure 1 and Figure 2 also show a stronger correlation between symbolic racism and attitudes toward White liberals relative to Blacks liberals $(p<.001)$ and relative to Hispanic liberals $(p=.03)$ among White and Non-White respondents. Those with scores one standard deviation below the mean on symbolic racism reported more positive attitudes toward Black liberals $(M=86.96, S D=17.40)$ relative to White liberals $(M=78.88, S D$ $=21.62), t(174)=7.04, p<.001, d=.53$. They also reported more positive attitudes toward Hispanic liberals relative to White liberals $(M=84.33, S D=19.06), t(174)=5.65, p<.001, d$ $=.43$. Additionally, those one standard deviation above the mean in symbolic racism reported more positive attitudes toward White liberals $(M=35.48, S D=29.15)$ relative to Black liberals $(M=31.42, S D=27.42), t(159)=3.02, p=.003, d=.24$. However, they did not report more positive attitudes toward White liberals relative to Hispanic liberals $(M=34.90, S D=27.92)$, $t(159)=.433, p=.665, d=.04$.

Importantly, symbolic racism more closely tracks attitudes toward ideological as opposed to racial groups. Disparities in target ratings at the high and low end of the symbolic racism scale are consistent with ingroup favorability effects at the high end and outgroup favorability effects at the low end. The ingroup favorability effects at the high end of the symbolic racism scale are considerably smaller than the outgroup favorability effects at the low end of the symbolic racism scale. The latter are consistent with heightened racial sympathy (Carney \& Enos, 2017) or by motivations to appear non-prejudiced (Wright \& Esses, 2017; Wright et al., 2020). Importantly, 
those who score high in symbolic racism still rate Black, Hispanic, and White conservatives relatively favorably, while those low in symbolic racism still rate Black, Hispanic, and White conservatives relatively unfavorably.

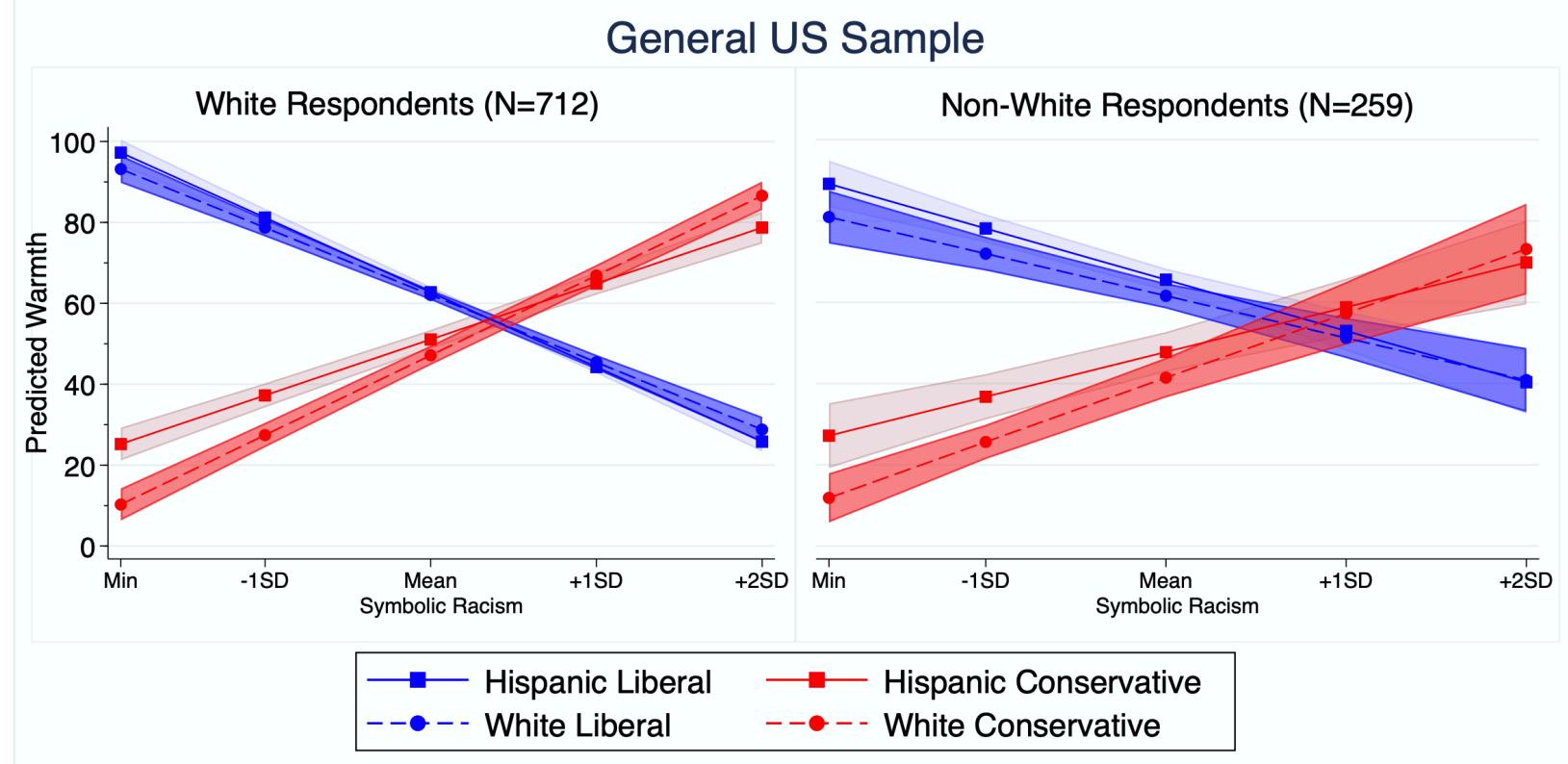

Figure 2. Relationships between symbolic racism and attitudes toward Hispanic liberals, White liberals, Hispanic conservatives, and White conservatives with $95 \%$ confidence intervals.

\section{Study 3}

Study 3 addresses three potential concerns regarding Study 1 and Study 2. First, we wanted to examine if our findings would replicate within a design that eliminates the potential for order effects. In Studies 1 and 2, all participants completed attitude thermometer ratings for all targets. Despite completing these in a random order, this could lead to matching effects, wherein participants can match thermometer ratings for target race. For example, once participants have rated white conservatives, they could match their rating of black conservatives to their rating of white conservatives to eliminate the appearance of anti-Black attitudes. Alternatively, individuals could boost ratings of Blacks relative to Whites in order to project a pro-Black attitude. By eliminating the potential for participants to alter ratings based upon how 
they have already rated another racial category, we eliminate the potential for artificially deflating anti-Black attitudes among those scoring high on symbolic racism or artificially inflating pro-Black attitudes among those scoring low on symbolic racism.

Second, we wanted to examine if the identified patterns would appear using a less obtrusive indicator of race. In Studies 1 and 2, participants responded to attitude thermometers toward obtrusive targets (e.g., "Black conservatives"). Participants may be inclined to inhibit negative attitudes or even inflate positive attitudes in such circumstances, depending upon their social desirability concerns. In Study 3, we avoid this by framing the rating task around favorability toward political candidates rather than obtrusive labels of Black versus White and liberal versus conservative. Third, because our interest is in the extent to which the symbolic racism scale tracks participants' attitudes toward perceived political ideology or race, we wanted to assess targets with more variability in political ideology to evaluate whether the attitudinal preferences of high vs. low scorers on symbolic racism apply across more varied political ideologies (e.g., high scorers favoring strong White conservatives over strong Black conservatives but not moderate White conservatives over moderate Black conservatives or low scorers favoring strong Black liberals over strong White liberals but not moderate Black liberals over moderate White liberals.

\section{Method}

We recruited 800 participants to participate in a study on "Perceptions of Political Candidates" using TurkPrime. All participants received the following instructions:

"We will present you with a selection of hypothetical political candidates, who are running as independents, and some basic information about each candidate's political orientation. The political orientation of each candidate was determined by an independent sample of raters. We provided each candidate's position on key issues to a sample of raters and asked these raters to provide a single indicator of political orientation using a scale from 1, "very liberal" to 7, "very conservative". For each candidate, we averaged 
the scores from the group of independent raters in order to determine our estimate of the political orientation of each candidate. Based upon this information, we would like you to report the extent to which you feel positively or negatively toward each candidate that follows."

We randomized participants into one of four conditions. In each condition, participants rated two target candidates who did not differ on race but did differ on political ideology. Candidates were rated on the same attitude thermometer as in Studies 1 and 2. The four conditions were as follows:

1. White candidates who were either strongly liberal or strongly conservative

2. White candidates who were either moderately liberal or moderately conservative

3. Black candidates who were either strongly liberal or strongly conservative

4. Black candidates who were either moderately liberal or moderately conservative We selected White and Black faces matched on age and attractiveness from the Chicago Face database (Ma et al., 2015). Same-race targets were also matched on skin luminosity. Within conditions, the pairing of political ideology (liberal vs. conservative) and face were counterbalanced, such that Face A and Face B were paired with liberal versus conservative labels half of the time. Figure 3 presents an example of the manipulation, which is available in full on the Open Science Framework (https://osf.io/hg86q/). Because each participant only rated Black or White candidates and rated one liberal and one conservative, a given participant could not equalize responses between the Black and White targets of the same ideological group. Following completion of the attitude thermometers, participants completed the SR-2000 and demographic questions. 


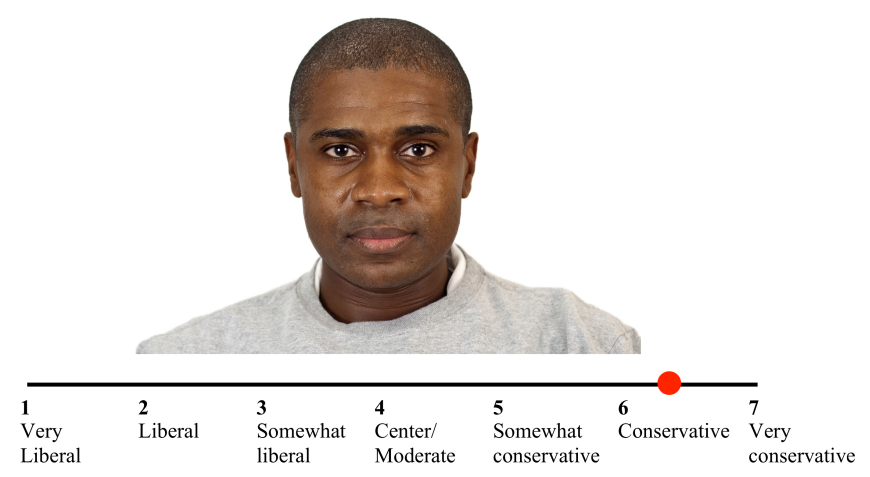

Figure 3. Example of a "Strong Conservative Black" manipulation used in Study 3.

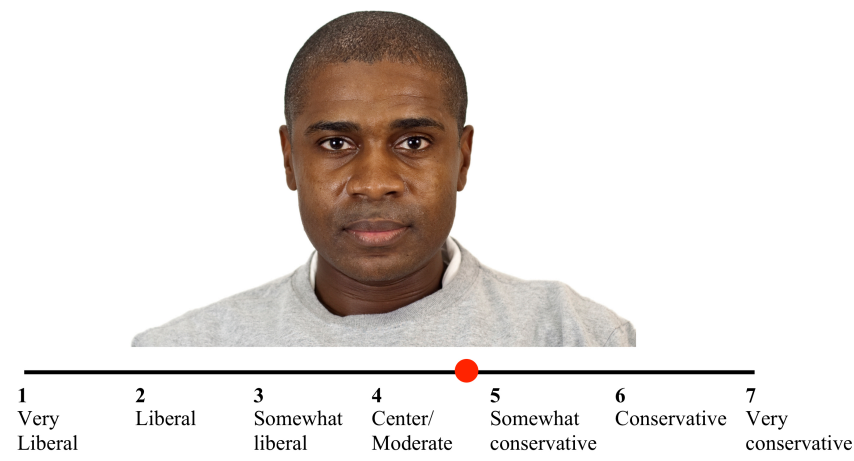

Figure 4. Example of a "Moderate Conservative Black" manipulation used in Study 3. 


\section{Results and Discussion}

Table 2.

Descriptive statistics and correlations between symbolic racism and targets used in Study 3.

\begin{tabular}{llllll}
\hline & Conservatism & $\begin{array}{l}\text { Symbolic } \\
\text { Racism }\end{array}$ & Mean & SD & $N$ \\
\hline 1. Conservatism & & & 4.30 & 1.84 & 801 \\
2. Symbolic Racism & .62 & & 3.83 & 1.25 & 801 \\
3. Strong Conservative White & .65 & .51 & 48.13 & 26.70 & 204 \\
4. Strong Conservative Black & .57 & .40 & 56.09 & 27.65 & 197 \\
5. Moderate Conservative White & .47 & .42 & 54.26 & 20.72 & 201 \\
6. Moderate Conservative Black & .52 & .36 & 58.72 & 20.78 & 198 \\
7. Strong Liberal White & -.40 & -.34 & 54.79 & 27.74 & 204 \\
8. Strong Liberal Black & -.41 & -.39 & 52.78 & 28.12 & 198 \\
9. Moderate Liberal White & -.16 & -.15 & 54.44 & 21.21 & 201 \\
s & -.15 & -.22 & 57.80 & 20.35 & 198 \\
\hline
\end{tabular}

Descriptive statistics are reported in Table 2. We evaluated the correlations between symbolic racism and attitudes toward Moderate Black Liberals, Moderate Black Conservatives, Moderate White Liberals, Moderate White Conservatives, Strong Black Liberals, Strong Black Conservatives, Strong White Liberals, and Strong White Conservatives (see Figure 4). Symbolic racism was associated with more positive attitudes toward strong conservative Whites $(r=.51$, 95\% CI: .40, .61), strong conservative Blacks ( $r=.40,95 \%$ CI: .26, .52), moderate conservative Whites ( $r=.42,95 \% \mathrm{CI}: .30, .52)$, and moderate Conservative Blacks ( $r=.36,95 \% \mathrm{CI}: .23, .49)$. Symbolic racism was also associated with more negative attitudes toward strong liberal Whites $(r=-.34,95 \%$ CI: $-.46,-.21)$, strong liberal Blacks $(r=-.39,95 \%$ CI: $-.50,-.27)$, moderate 
liberal Whites $(r=-.15,95 \%$ CI: $-.28,-.01)$, and moderate liberal Blacks $(r=-.22,95 \%$ CI: -.36 , $-.09)$.
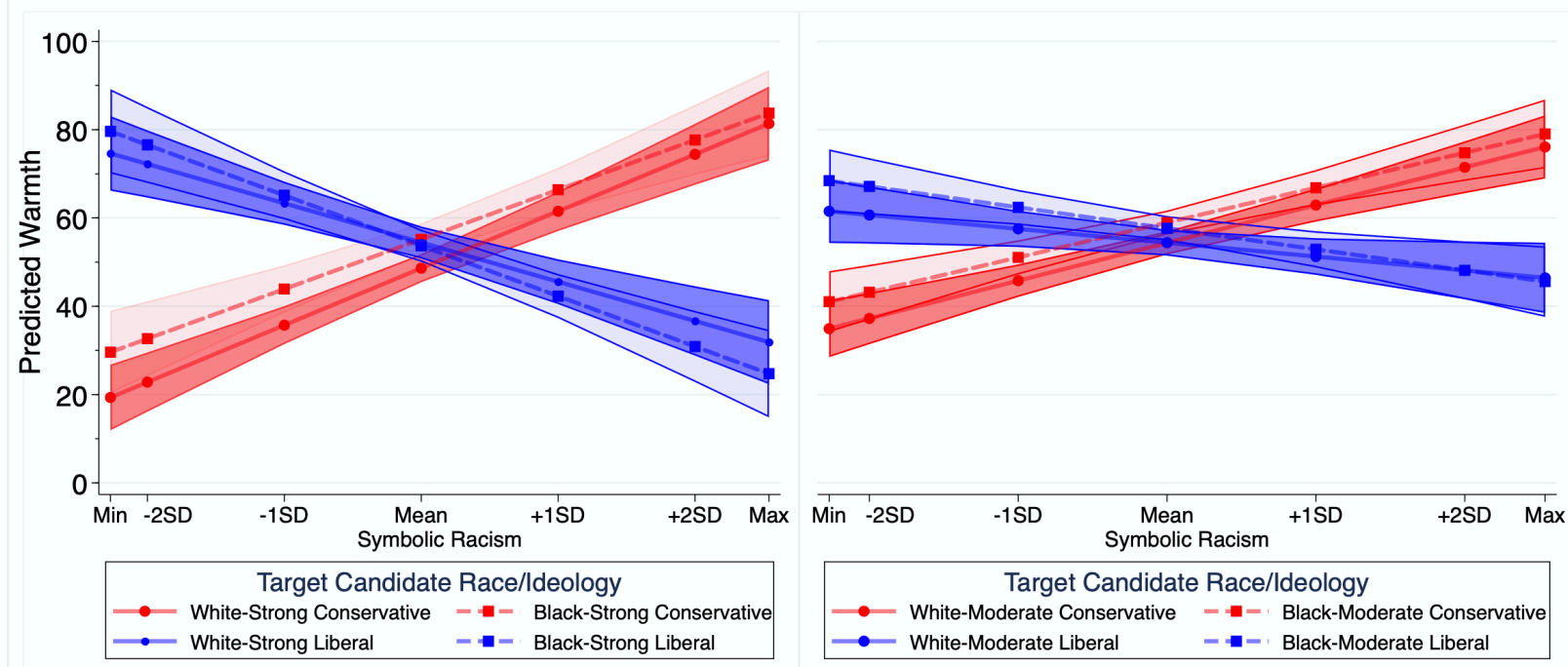

Figure 4. Relationships between symbolic racism and attitudes toward each target with 95\% confidence intervals.

In contrast with Study 1 and Study 2, there was no statistically significant difference in correlations between symbolic racism and attitudes toward strong conservative Whites versus strong conservative Blacks $(p=.14)$, nor was there a statistically significant difference in correlations between symbolic racism and attitudes toward moderate conservative Whites versus moderate conservative Blacks $(p=.55)$.

\section{Attitudes toward Candidates with Moderate and Strong Ideologies for High vs. Low Scorers}

\section{on Symbolic Racism}

Those with scores greater than one standard deviation above the mean on symbolic racism did not differ in attitudes toward strong conservative Whites $(M=54.35, S D=24.05)$ relative to strong conservative Blacks $(M=54.43, S D=26.26), t(44)=0.01, p=.99, d=.003$. They also did not differ in attitudes toward moderate conservative Whites $(M=56.27, S D=$ 
15.77) relative to moderate conservative Blacks $(M=62.30, S D=19.76), t(47)=1.19, p=0.24$, $d=-.33$. Those with scores one standard deviation below the mean on symbolic racism did not differ in attitudes toward strong conservative Blacks $(M=28.45, S D=20.89)$ relative to strong conservative Whites $(M=23.65, S D=18.97), t(70)=1.01, p=.32, d=.24$. Likewise, they did not differ in attitudes toward moderate conservative Blacks $(M=42.85, S D=17.79)$, relative to moderate conservative Whites $(M=36.36, S D=19.74), t(67)=1.43, p=.16, d=0.35$.

Likewise, there was no statistically significant difference in correlations between symbolic racism and attitudes towards strong liberal Blacks versus strong liberal Whites ( $p$ $=.53$ ), nor was there a statistically significant difference in correlations between symbolic racism and attitudes toward moderate liberal Blacks versus moderate liberal Whites $(p=.22)$. Those with scores one standard deviation above the mean on symbolic racism did not differ in attitudes toward strong liberal Blacks $(M=25.48, S D=23.33)$ relative to strong liberal Whites $(M=$ 28.62, $S D=24.74), t(47)=0.46, p=.65, d=.13$. Likewise, they did not differ in attitudes toward moderate liberal Whites $(M=36.62, S D=19.15)$ relative to moderate liberal Blacks $(M=$ $39.39, S D=22.37), t(47)=0.47, p=.64, d=-.13$. Finally, those with scores one standard deviation below the mean on symbolic racism did not differ in attitudes toward strong liberal Blacks $(M=76.59, S D=17.66)$ relative to strong liberal Whites $(M=70.91, S D=22.07), t(70)$ $=1.16, p=.25, d=.28$. However, they did report considerably more favorable attitudes toward moderate liberal Blacks $(M=65.48, S D=17.46)$ relative to moderate liberal Whites $(M=54.61$, $S D=19.47), t(67)=2.43, p=.02 d=.59$.

Attitudes toward Conservative versus Liberal Candidates (Combining Candidates with Moderate and Strong Ideologies) for High vs. Low Scorers on Symbolic Racism 
We also examined averaged attitudes toward candidates with moderate and strong ideologies in order to provide a comparison with Studies 1 and 2. Those with scores greater than one standard deviation above the mean on symbolic racism did not differ in attitudes toward conservative Whites $(M=55.31, S D=20.16)$ relative to conservative Blacks $(M=58.37, S D=$ 23.32), $t(96)=0.69, p=.49, d=-.14$. Those with scores one standard deviation below the mean on symbolic racism reported marginally more positive attitudes toward conservative Blacks $(M=$ $36.11, S D=20.46)$ relative to conservative Whites $(M=29.44, S D=20.23), t(139)=1.93, p$ $=.06, d=.33$.

There was no statistically significant difference in correlations between symbolic racism and attitudes towards strong liberal Blacks versus strong liberal Whites $(p=.53)$, nor was there a statistically significant difference in correlations between symbolic racism and attitudes toward moderate liberal Blacks versus moderate liberal Whites $(p=.22)$. Those with scores one standard deviation above the mean on symbolic racism did not differ in attitudes toward liberal Blacks $(M$ $=32.43, S D=23.67)$ relative to liberal Whites $(M=32.62, S D=22.27), t(96)=0.04, p=.97, d$ $=0.01$. Finally, those with scores one standard deviation below the mean on symbolic racism reported marginally more positive attitudes toward liberal Blacks $(M=70.68, S D=18.28)$ relative to liberal Whites $(M=63.48, S D=22.34), t(139)=2.05, p=.04, d=0.35$.

\section{Relations Between Symbolic Racism and Attitudes toward Candidates with Strong vs. Weak}

\section{Ideologies}

A notable observation from Figure 4 is that the correlations between symbolic racism and attitudes toward candidates seem to be stronger when the candidates have strong as opposed to weak ideologies, which would be consistent with symbolic racism tracking political ideology. We found no statistical difference in strength of correlations between symbolic racism and 
attitudes toward strong vs. moderate White conservatives $(p=.13)$, or between symbolic racism and attitudes toward strong vs. moderate Black conservatives $(r=.32)$. However, we did find that symbolic racism had a stronger negative correlation with attitudes toward strong vs. moderate White liberals $(p=.02)$ and a stronger negative correlation with attitudes toward strong vs. moderate Black liberals $(p=.03)$, suggesting that symbolic racism measures anti-liberal attitudes.

\section{General Discussion of Studies 1-3}

Confirming the results of Studies 1 and 2, the results of Study 3 indicated that symbolic racism scores are correlated with attitudes toward political targets, rather than racial targets. Symbolic racism is positively associated with attitudes toward conservatives and negatively associated with attitudes toward liberals, regardless of the race of the target. In Studies 1 and 2, we did find that symbolic racists showed a small preference for conservative Whites versus conservative Blacks $\left(d_{\text {Study } 1}=0.33 ; d_{\text {Study } 2}=0.21\right)$ and mixed evidence for a preference for liberal Whites versus liberal Blacks $\left(d_{\text {Study } 1}=0.03 ; d_{\text {Study } 2}=0.24\right)$. When we eliminated the potential for "matching" by having participants only report attitudes toward targets who did not differ on race but did differ on political ideology in Study 3, these small effects disappeared. In this case, "symbolic racists" showed no demonstrable bias in favor of White conservatives over Black conservatives $(d=-0.15)$, and in fact, the effect was in the opposite direction. We also found no demonstrable bias in favor of White liberals over Black liberals $(d=0.01)$. In contrast, low scorers on the symbolic racism scale showed clear favoritism of one racial group over another. These racial sympathizers showed moderate favoritism toward Black conservatives versus White conservatives $\left(d_{\text {Study } 1}=0.47 ; d_{\text {Study } 2}=0.66, d_{\text {Study } 3}=0.33\right)$ and moderate favoritism toward Black liberals versus White liberals $\left(d_{\text {Study } 1}=0.31, d_{\text {Study } 2}=0.53, d_{\text {Study } 3}=0.35\right)$. 
Calculating weighted effects by sample size for each study, our results show an unambiguous pattern of racial sympathizers showing favoritism in attitudes toward Black versus White conservatives $(d=0.50)$ and Black versus White liberals $(d=0.42)$. In contrast, we find little evidence that symbolic racists favor White versus Black conservatives $(d=0.15)$ or favor White versus Black liberals $(d=0.12)$.

\section{Study 4 and Study 5}

In Studies 4 and 5, we examine the association between symbolic racism and attitudes toward more specific targets. While the previous targets were generic crosses of race with ideology, the American National Election Study (ANES) provides a plethora of real targets, which includes both people and groups. We use these data to further examine the relationship between symbolic racism toward Blacks and attitudes toward targets that reflect both liberalconservative and racial dimensions (e.g., Ben Carson is a Black conservative while Barack Obama is a Black liberal).

\section{Method}

We used the ANES 2016 Time Series data and the ANES 2018 Pilot Study data. For full information regarding the ANES, see https://electionstudies.org.

ANES 2016. The ANES 2016 uses a probability sampling procedure that includes geographic stratified cluster sampling, oversampling from minority groups, and random sampling within households to obtain a nationally representative sample of U.S. citizens who are 18 years of age or older and living in the 50 U.S. states or the District of Columbia. All variables of interest for the current paper come from the post-election survey, which was collected between November 9, 2016 and January 8, 2017. This survey includes four items from the SR-2000 and is often referred to as the racial resentment scale. 
Responses are captured on a scale from 1, "agree strongly" to 5, "disagree strongly" before reverse coding relevant items and computing a mean score with higher scores indicating more symbolic racism $(\alpha=.85)$. Additionally, participants completed attitude thermometers toward people (e.g., Ben Carson \& Barack Obama), ethnic/racial groups (e.g., Blacks \& Whites), and other groups or movements (e.g., Black Lives Matter \& the Tea Party). The ANES 2016 contains 3,603 respondents that completed the symbolic racism measure and at least one of the attitude thermometers.

ANES 2018. The ANES 2018 pilot survey was conducted in December 2018 using nonprobability sampling. This method produces a sample that looks similar to a probability sample on matched characteristics (gender, age, race, and education) but may still differ in unknown ways on unmatched characteristics. The survey included the same four item symbolic racism scale as the ANES $2016(\alpha=.88)$ and included attitude thermometers toward people (e.g., Brett Kavanaugh \& Hillary Clinton), ethnic/racial groups (e.g., Blacks \& Whites), and other groups or movements (e.g., Alt-Right \& "Me Too"). The ANES 2018 contains 2,494 respondents that completed the symbolic racism measure and at least one of the attitude thermometers.

\section{Results and Discussion}

We computed unstandardized regression coefficients by regressing each attitude thermometer rating onto symbolic racism. We used pairwise deletion for missing values. Sample sizes for calculating regression coefficients ranged from $N=3110$ to $N=3603$ in the 2016 data and $N=2011$ to $N=2494$ in the 2018 data. These coefficients are plotted in Figure 5. The clear pattern that emerges is that symbolic racism is associated with more negative attitudes toward liberal targets and more positive attitudes toward conservative targets, regardless of the race of the target. For instance, symbolic racists express more positive attitudes toward Ben Carson, a 
black man, than toward Hillary Clinton, a white woman, and express more negative attitudes toward Hillary Clinton than the broader category of Blacks. In fact, symbolic racism was more associated with negative attitudes toward Robert Mueller $\left(b_{2018}=-19.20,95 \%\right.$ CI: -20.64 , 17.75), Tim Kaine $\left(b_{2016}=-10.14,95 \%\right.$ CI: $\left.-11.14,-9.15\right)$, MeToo $\left(b_{2018}=-21.51,95 \%\right.$ CI: $22.68,-20.33)$, Bill Clinton $\left(b_{2016}=-12.78,95 \%\right.$ CI: $\left.-13.91,-11.66\right)$, Hillary Clinton $\left(b_{2016}=-\right.$ 16.89, 95\% CI: $-17.97,-15.81 ; b_{2018}=-20.38,95 \%$ CI: $\left.-21.69,-19.08\right)$, and Feminists $\left(b_{2016}=-\right.$ $11.55,95 \% \mathrm{CI}:-12.47,-10.64)$ relative to Blacks $\left(b_{2016}=-7.73,95 \% \mathrm{CI}:-8.48,-6.94 ; b_{2018}=-\right.$ $8.37,95 \% \mathrm{CI}:-9.51,-7.22)$, which is not consistent with symbolic racism as a measure of antiBlack affect. Rather than measuring anti-Black affect, this is more parsimoniously explained by anti-liberal affect (i.e., conservatives dislike liberal targets).

The weakest relationships with symbolic racism are those for groups that are less homogenously liberal or conservative. For instance, symbolic racism is only weakly associated with more positive attitudes toward Whites $\left(b_{2016}=2.06,95 \% \mathrm{CI}: 1.22,2.09 ; b_{2018}=5.88,95 \%\right.$ CI: 4.72, 7.04), presumably because Whites are a mixed ideological group, with 58\% voting Republican and 37\% voting Democrat in the 2016 election; Huang et al, 2016). Similarly, symbolic racism is only weakly associated with more negative attitudes toward Asians $\left(b_{2016}=\right.$ 4.18, 95\% CI: $-5.02,-3.34 ; b_{2018}=-5.08,95 \%$ CI: $-6.37,-3.79 ; 65 \%$ voting Democrat and $29 \%$ voting Republican $)$ and poor people $\left(b_{2016}=-3.18,95 \%\right.$ CI: $-3.96 ; 53 \%$ voting Democrat and $41 \%$ voting Republican, Huang et al., 2016). Compare these to the more obviously liberalconservative targets such as homosexual targets $\left(b_{2016}=-10.32,95 \% \mathrm{CI}:-11.37,-9.26 ; 78 \%\right.$ voted Democrat), Democrats $\left(b_{2016}=-13.62,95 \% \mathrm{CI}:-14.63,-12.62 ; 89 \%\right.$ voted Democrat $)$, Republicans $\left(b_{2016}=12.07\right.$, 95\% CI: 11.12, $13.01 ; 90 \%$ voted Republican $)$, or the most prototypical leaders for the respective parties (Barack Obama, $b_{2016}=-21.25,95 \%$ CI: -22.27 , - 
20.23; $b_{2018}=-24.95,95 \%$ CI: $-26.29,-23.61$; Donald Trump, $b_{2016}=18.96,95 \%$ CI: 17.93 , $\left.20.00 ; b_{2018}=27.75,95 \% \mathrm{CI}: 26.54,28.96\right)$. It is clear that as the liberal-conservative status of a target strengthens, so too does the strength of the relationship between symbolic racism and attitudes toward the target. In contrast, this is not the case for the White-Black status of the targets.

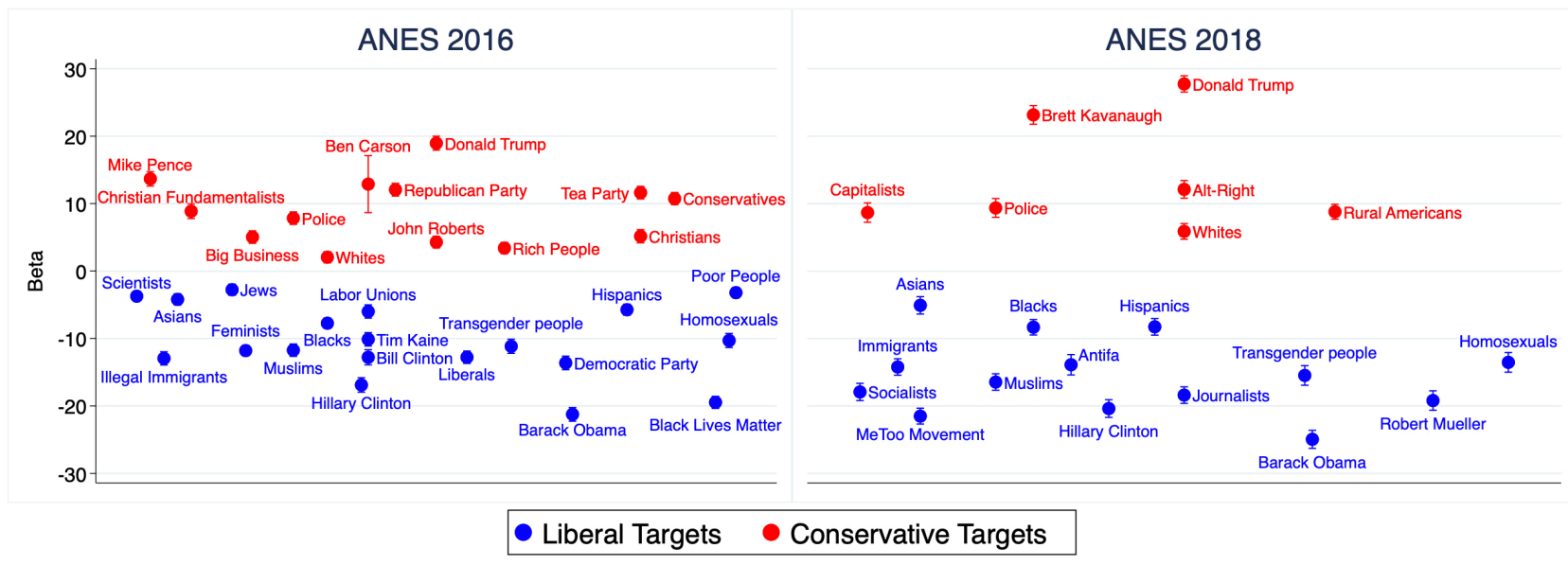

Figure 5. Change in predicted attitudes toward targets for each point change in symbolic racism toward Blacks in the ANES 2016 Time Series and the ANES 2018 Pilot Study.

\section{Study 6}

Studies 1 through 3 demonstrated that the association between symbolic racism and attitudes towards White and non-White targets are largely conditional on the ideological orientation of the target. Regardless of whether we examine individuals at the high end of the scale (i.e., symbolic racists), or the low end of the scale (i.e., racial sympathizers), we consistently find that participants show convergence in their attitudes toward the political "other" rather than the racial "other". High scorers are more positive toward conservatives and less positive toward liberals regardless of racial group and low scorers are less positive toward conservatives and more positive toward liberals regardless of the racial group of the target. Additionally, we found substantial evidence of pro-Black/anti-White attitudes for low scorers 
both in their attitudes toward Conservatives $(d=.50)$ and in their attitudes toward Liberals $(d$ $=.42$ ) but little evidence of anti-Black/pro-White attitudes for high scorers in their attitudes toward Conservatives $(d=.15)$ or in their attitudes toward Liberals $(d=.12)$. Studies 4 and 5 demonstrated that these effects hold across a plethora of real targets (including people, places, and movements). Study 6 extends these findings by examining whether the association between symbolic racism and attitudes toward racial targets is conditional on the socioeconomic class, gender, or religious affiliation of the target. Specifically, do symbolic racists report less favorable attitudes towards poor/rich black men and women but more favorable attitudes towards their white counterparts? In contrast, do respondents with low scores on symbolic racism exhibit greater egalitarianism in their ratings? Is it the case that the high scoring respondents reserve their positivity for White Christians while the low scoring respondents are racially neutral? If the symbolic racism measure is generally an index of anti-black affect, we would expect to answer 'yes' to these questions. However, if the scale is more generally measuring fundamental aspects of conservative ideology, such as individualism (e.g., Carney \& Enos, 2017), we would expect the answers to be more complicated. For instance, if symbolic racists have stronger meritocracy beliefs, it is plausible that they would be similarly positive towards economically successful or unsuccessful Black men and women as they are towards their White counterparts. Conversely, if racial sympathizers tend to be more strongly committed to contemporary liberal ideology, including the belief that all Whites enjoy unique racial advantages, we might expect them to demonstrate pro-Black/anti-White attitudes. Alternatively, or in addition, the public's association of Whites with the Republican party (e.g., Valentino and Zhirkov, 2018) might entail that White targets are perceived, and thus treated, as members of the political out-group by liberal respondents. In Study 6, we utilize a publicly available survey to examine these questions. 


\section{Method}

We use data from the 2016 and 2019 waves of the Democracy Fund's Voter Study Group (VSG). The VSG is a YouGov panel survey of 8,637 adult respondents. Of this sample, 5,948 are classified as 'long-term respondents' or those that participated in 3 or more of the 5 survey waves. Wave 1 of the VSG commenced in December 2011 and was followed by interviews in December 2016 (Wave 2), July 2017 (Wave 3), May 2018 (Wave 4), and January 2019 (Wave 5). YouGov employs a matching procedure that matches the panel's demographics with those observed in the US Census Bureau's American Community Survey, Current Population Survey, and other databases. Additional information about the VSG sample and survey methodology can be found at https://www.voterstudygroup.org/publication/2019-voter-survey-full-data-set.

The panelists $(N=5,650)$ retained in the current study are those that completed both the standard 4-item measure of symbolic racism during Wave 2 of the study (December 2016) as well as the new set of group feeling thermometers that were added in Wave 5 (January 2019). Of the sample, $81 \%$ identified as White and $51 \%$ identified as female. The median year of birth was 1958.

Panelists indicate their feelings on a 0 (cold) -100 (warm) scale towards the following target groups: Poor/rich White men/women and poor/rich Black men/women, White Christians, Black Christians, and Hispanic Christians. Panelists were randomly assigned two thermometers from the race-SES series and one from the set of three Christian racial-groups. Sample sizes featured in our analyses of each race-SES (Christian) target ranged from 1,072-1,157 (879-914) for White and 241-269 (186-209) for non-White panelists, respectively.

\section{Results and Discussion}


Our analytical strategy mirrors that of Studies 4 and 5. We regress each group feeling thermometer on symbolic racism for White and non-White respondents. In addition to comparing the strength of the relationships for each subgroup, we also assess how effective symbolic racism is at predicting anti-Black attitudes at different points along the scale. The results for the genderrace-SES series are displayed in Figure 6 below. $^{3}$ The left panels show the effects of symbolic racism on attitudes towards poor (rich) Black and White men for White respondents and nonWhite respondents.
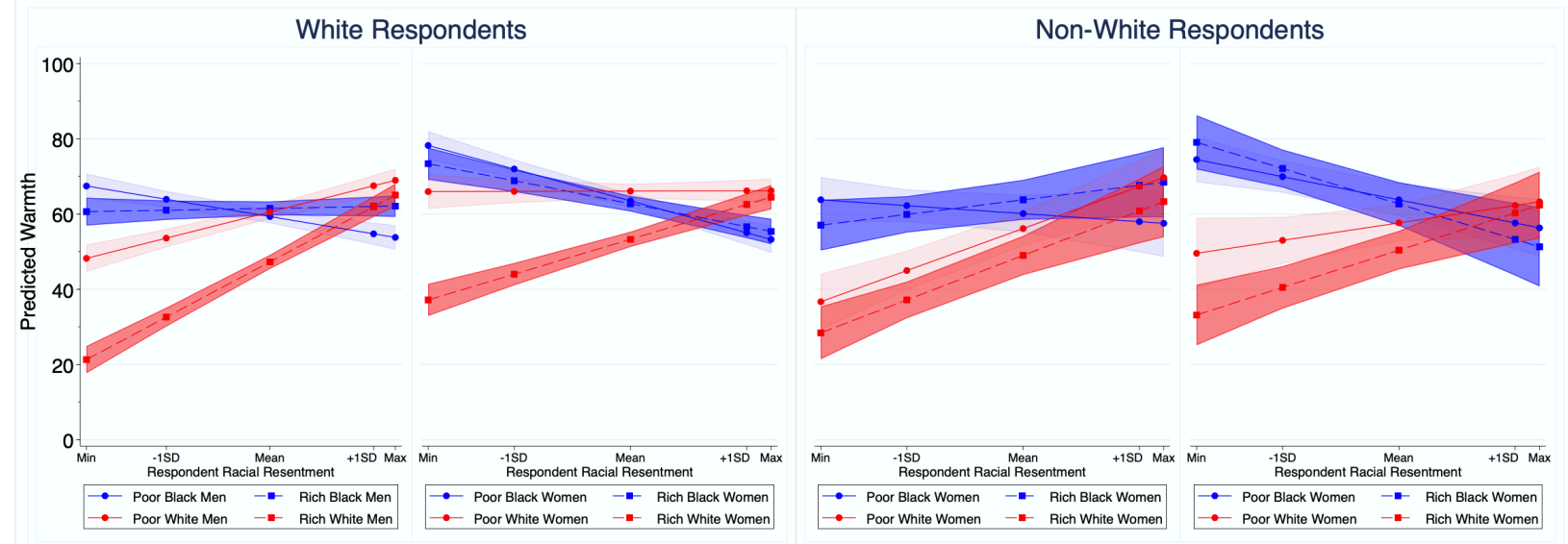

Figure 6. Relationships between symbolic racism and attitudes toward target groups with 95\% confidence intervals.

First, symbolic racism is more strongly associated with attitudes towards poor Whites $\left(b_{\mathrm{w}}{ }^{4}=6.89, \mathrm{CI}: 5.06,8.72 ; b_{\mathrm{nw}}=11.18, \mathrm{CI}: 7.83,14.50\right)$ than poor Blacks $\left(b_{w}=-4.42, \mathrm{CI}:-6.58,-\right.$ $\left.2.26 ; b_{\mathrm{nw}}=-2.12, \mathrm{CI}:-6.49,2.25\right)$. The difference in these coefficients is not statistically significant $(p=.087)$ for White respondents but is for non-White respondents $(p=.003)$. The most racist White respondents — those scoring at the scale maximum — rate poor Blacks just above the midpoint $(M=54.17, \mathrm{CI}: 50.3,58.03)$ of the feeling thermometer. In contrast, they rate

\footnotetext{
${ }^{3}$ A table of parameter estimates for both subgroups is provided in the Appendix.

4 The subscripts ' $w$ ' and 'nw' refer to white and non-white respondents, respectively.
} 
poor Whites at 69 (CI: 66.5, 71.9). This is consistent with the intended function of the symbolic racism scale. However, among the least symbolically racist White respondents, poor Blacks and Whites were rated at 67 (CI: 63.4, 70.8) and 49 (CI: 45.1, 52.2), respectively. The least symbolically racist White respondents were significantly more negative $(p=.045)$ towards poor Whites than the most symbolically racist were negative towards poor Blacks. This is consistent with our findings from Studies 1, 2, and 3, in which the least symbolically racist respondents tend to show greater attitudinal disparities toward Black versus White targets than do the most symbolically racist respondents.

This disparity is even greater when comparing attitude ratings for rich Blacks and Whites. Symbolic racism is more strongly associated with attitudes towards rich Whites $\left(b_{\mathrm{w}}=14.8, \mathrm{CI}\right.$ : $\left.13.04,16.62 ; b_{\mathrm{nw}}=11.82, \mathrm{CI}: 8,15.6\right)$ than rich Blacks $\left(b_{\mathrm{w}}=0.55, \mathrm{CI}:-1.37,2.47 ; b_{\mathrm{nw}}=3.86, \mathrm{CI}\right.$ $=0.07,7.65)$ for both White and non-White respondents. Among White respondents, the association between symbolic racism and attitudes towards rich Blacks are indistinguishable from zero $(p=0.565)$. Additionally, the ratings for rich Whites $(M=65.3, \mathrm{CI}=62.4,68.2)$ and rich Blacks $(M=62.3, \mathrm{CI}: 59.8,64.7)$ among the most symbolically racist White respondents are virtually identical $(p=.17)$. However, among the least symbolically racist respondents, rich Blacks receive substantially more positive scores $(M=60.6, \mathrm{CI}: 56.2,65.02)$ relative to rich Whites $(M=21.7, \mathrm{CI}: 18.8,24.7)$. Furthermore, attitudes toward rich Whites among the least symbolically racist respondents is significantly lower than the same rating from their non-White counterparts $(M=28.06, \mathrm{CI}: 22.9,33.2), p=.036$. The disparate correlations between symbolic racism and attitudes toward rich Whites versus rich Blacks is a product of disparities in the attitudinal ratings of symbolic sympathizers, not symbolic racists, in which racial sympathizers show the greatest intergroup bias in thermometer ratings in favor of rich Blacks. 
Similar patterns are obtained for female targets (right panels of Figure 6). The most symbolically racist White panelists ${ }^{5}$ are significantly more positive towards poor White women $(M=66.2, \mathrm{CI}: 62.8,69.6)$ than poor Black women $(M: 53.2, \mathrm{CI}: 49.5,57)$. This disparity reverses itself among the least symbolically racist White panelists, who express more positive attitudes towards poor Black $(M=78.5, \mathrm{CI}: 74.2,82.3)$ relative to poor White $(M=66.0, \mathrm{CI}$ : 62.6, 69.3) women. This disparity in favor of poor Black women $(M=74.7, \mathrm{CI}: 69.2,80.1)$ is twice as large among the lowest scoring non-White panelists, who rate poor White women just below the midpoint $(M=49.4, \mathrm{CI}: 41.5,57.3)$. Whereas the most symbolically racist White and non-White panelists are moderately favorable towards rich White $\left(M_{\mathrm{w}}=64.5, \mathrm{CI}: 61.5,67.5\right.$; $\left.M_{\mathrm{nw}}=62.4, \mathrm{CI}=53.6,71.2\right)$ relative to Black women $\left(M_{\mathrm{w}}=55.4, \mathrm{CI}=51.8,58.9 ; M_{\mathrm{nw}}=51.3, \mathrm{CI}\right.$ $=39.6,62.9)$, the least symbolically racist respondents show a vast disparity in their attitudes toward rich Black $\left(M_{\mathrm{w}}=73.6, \mathrm{CI}: 69.4,77.7 ; M_{\mathrm{nw}}=79.3, \mathrm{CI}: 73.5,85.1\right)$ versus rich White women $\left(M_{\mathrm{w}}=36.9, \mathrm{CI}: 33.5,40.2 ; M_{\mathrm{nw}}=32.9, \mathrm{CI}: 22,43.7\right)$. Among those scoring high in symbolic racism, the ratings toward rich Black and rich White women are still categorically positive. In contrast, among those with the lowest scores on symbolic racism, rich White women are rated categorically negatively, while rich Black women are rated categorically positively. Similar patterns exist when we examine attitudes toward Christian racial groups (see Figure 7). First, the association between symbolic racism and attitude ratings is stronger for White Christians $\left(b_{\mathrm{w}}=18.1, \mathrm{CI}: 15.9,20.3 ; b_{\mathrm{nw}}=14.5, \mathrm{CI}: 9.0,20.0\right)$ than for their Black $\left(b_{\mathrm{w}}=\right.$ 2.5, CI: 0.09, 5.0; $\left.b_{\mathrm{nw}}=3.9, \mathrm{CI}:-3.9,11.6\right)$ and Hispanic $\left(b_{\mathrm{w}}=2.2, \mathrm{CI}:-0.13,4.6 ; b_{\mathrm{nw}}=-0.49, \mathrm{CI}\right.$ : -7.6, 6.8) counterparts. With the exception of its effects on White respondents' attitudes towards

\footnotetext{
${ }^{5}$ Attitudes towards poor Black $(M=56.3$, CI: $50.3,62.3)$ and White $(M=63.25$, CI: $55.4,71.1)$ women among the most resentful non-White panelists are statistically indistinguishable from those of their White counterparts. However, the differences between the two ratings only achieve conventional levels of significance for White panelists.
} 
Black Christians $\left(p_{\mathrm{w}}=0.042 ; p_{\mathrm{nw}}=0.328\right)$, symbolic racism is only a significant predictor of attitudes towards White Christians. The highest scoring White panelists on symbolic racism express more positive attitudes towards White Christians $(M=83.6, \mathrm{CI}: 80.9,86.3)$ relative to Black $(M=70.7, \mathrm{CI}: 66.5,74.9)$ and Hispanic $(M: 66.5, \mathrm{CI}=62.9,70.1)$ Christians. ${ }^{6}$ Despite this pro-White favoritism among strong symbolic racists, their ratings of Black and Hispanic Christians are not only categorically positive, but also marginally more positive than the ratings that Black $(p=.04)$ and Hispanic Christians $(p=.06)$ receive from the racial sympathizers. The anti-White Christian bias among White racial sympathizers is approximately twice as large as the anti-Black and anti-Hispanic Christian bias among White symbolic racists. Importantly, only among the least racist respondents do we find categorically negative attitudes toward any racial group. Whereas Black and Hispanic Christians receive relatively positive scores $(M=63, \mathrm{CI}$ : 59.3, 66.9 and $M=59.8, \mathrm{CI}: 55.5,64.1)$ among White racial sympathizers, White Christians are viewed exceptionally negatively by these same panelists $(M=29.6, \mathrm{CI}: 24.4,34.8)$.

\footnotetext{
${ }^{6}$ The most resentful non-white panelists are even less positive towards Hispanic Christians $(M=54.2, \mathrm{CI}=42.2$, 66.2), but the difference between them and the most resentful white panelists falls short of conventional thresholds of significance $(p=.081)$.
} 


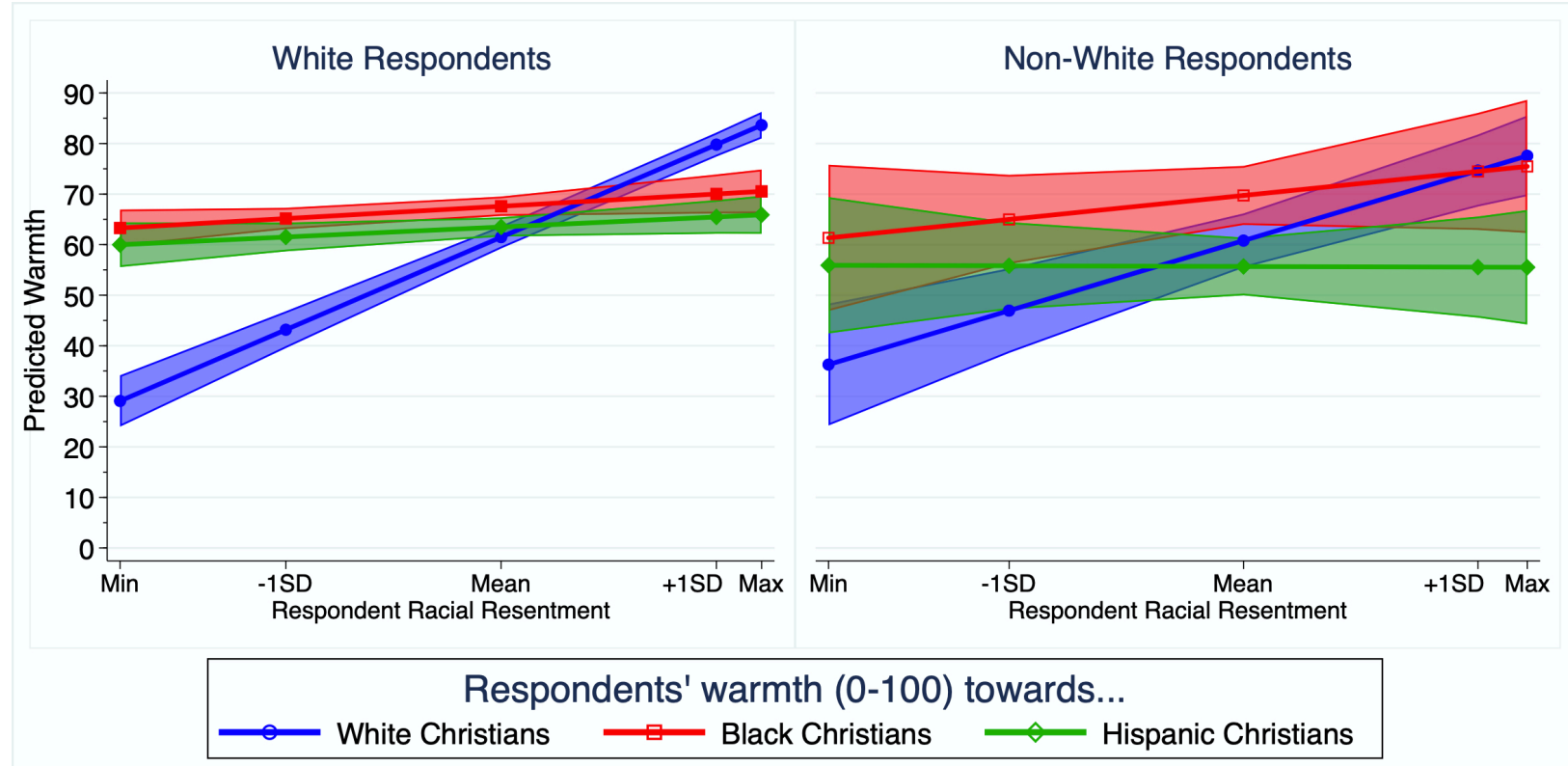

Figure 7. Relationship between symbolic racism and attitudes toward target groups with 95\% confidence intervals.

We consistently demonstrate that symbolic racism captures something far beyond antiBlack prejudice. We contend that this 'something' amounts to differences in ideological, as opposed to, racial affinities. This is directly supported by the following consistencies. First, the high scorers on symbolic racism are virtually as positive towards rich Black men as they are towards rich White men. Although a moderate but significant pro-White bias emerges when panelists are presented with poor/rich Black versus White female targets, this could be a function of the (intuited) fact that Black women are almost half as likely as men to identify as Republican. ${ }^{7}$ In Studies 4 and 5, we noted that symbolic racism scores tracked group targets in line with the percentages of those groups that voted Democrat or Republican in the 2016 election.

\footnotetext{
${ }^{7}$ According to the 2018 Cooperative Congressional Studies Survey, $10.8 \%$ of black men vs. $5.7 \%$ of black women identify as or lean Republican. Thus, it's possible that the most resentful panelists are more likely to conceive of rich black men as ideological or political allies.
} 
Second, with one exception (poor White women), the respondents with the lowest scores on symbolic racism rate all White targets negatively. Further, and with no exception, low scorers on symbolic racism rate Black targets more positively than corresponding White targets by large margins. This pro-Black/anti-White bias could be a reflection of a view that increasingly predominates among liberals — that Whites of all economic backgrounds enjoy unique advantages that are denied to Blacks. Alternatively, or in addition, it may reflect the increasing association of (even poor) Whites with supporters of the Republican party.

Finally, despite their moderate pro-White-Christian bias, the White panelists with the highest scores on symbolic racism were more positive towards non-White Christians than their least symbolically racist counterparts. If the symbolic racism scale were a valid measure of subtle anti-Black affect, this finding is puzzling. How could it be that the least symbolically racist Whites express more negative attitudes toward non-White Christians than the most symbolically racist of Whites? Instead, if symbolic racism is capturing ideological affinities, this finding is to be expected. For instance, given the association of Christian religiosity with conservatism and adherence to traditional values, the most symbolically racist White panelists likely view non-White Christians as members of their political ingroup (i.e., Conservatives). The results of Study 6 further strengthen the position that the symbolic racism scale captures far too much content beyond anti-Black affect to be treated as a valid index of anti-Black affect. Additionally, it corroborates the finding from Studies 1 through 3 that the racial sympathizers (low scorers on symbolic racism) show the greatest attitudinal disparities between racial targets.

\section{General Discussion}

After 30 years of research on symbolic racism, Sears and Henry (2005) claimed that symbolic racism "focuses on antagonism toward Blacks" (p. 96), a consistent claim since the 
creation of the construct (Kinder \& Sears, 1981; McConahay \& Hough Jr, 1976). After six studies totaling 14,078 participants, including three nationally representative samples, we find consistent evidence that symbolic racism predicts attitudes toward ideologically convergent and divergent target groups rather than racially convergent and divergent target groups. Symbolic racism appears to reflect more anti-liberal sentiment than anti-Black sentiment and the greatest disparities in attitudes toward different racial groups occurs among the lowest scoring respondents on the symbolic racism scale.

\section{Anti-Black Affect}

Even though our results suggest more evidence for anti-Liberal attitudes relative to antiBlack attitudes, there may be residual effects of anti-Black affect in measures of symbolic racism. Symbolic racism was more strongly associated with positive attitudes toward White conservatives relative to Black conservatives and more strongly associated with negative attitudes toward Black liberals relative to White liberals. These disparities are partly a function of the attitudes of high scorers. Those with relatively high scores on the symbolic racism scale do display modest ingroup favoritism in the form of relatively more positive attitudes toward White conservatives versus Black conservatives $(d=.15)$ and relatively more positive attitudes toward White liberals versus Black liberals $(d=.12) .{ }^{8}$ However, ingroup favoritism is the norm in intergroup relations (Tajfel, 1970; Tajfel et al., 1971; Tajfel \& Turner, 1979) and it does not imply animosity toward outgroups (Brewer, 1999; McGarty, 2001; Mummendey et al., 2001; Mummendey et al., 1992). In fact, the highest scoring respondents on symbolic racism consistently showed more positive attitudes toward outgroups than the lowest scoring respondents on symbolic racism scale and the symbolically racist respondents consistently rated

\footnotetext{
8 Weighted average effect sizes based upon studies 1-3
} 
conservative, rich, and Christian targets positively regardless of whether they were Black, Hispanic, or White and consistently rated liberal or poor targets negatively regardless of whether they were White, Hispanic, or Black.

\section{Racial Sympathy}

Those with relatively low scores on the symbolic racism scale display strong pro-Black favoritism, in the form of more positive attitudes toward Black liberals relative to White liberals $(d=.42)$ and more positive attitudes toward Black conservatives relative to White conservatives $(d=.50)$. Outgroup favoritism is non-normative and we suggest possible explanations for these effects. Liberals tend to show considerable racial sympathy toward Black targets (Carney \& Enos, 2017), possibly because they are especially responsive to righting past wrongs (Craemer, 2009). This is consistent with their emphasis on moral principles that stress compassion for groups perceived as vulnerable and stress equal outcomes as the basis of fairness (Graham, Haidt, \& Nosek, 2009; Schlenker et al., 2012). In addition, it is possible that low scorers on symbolic racism favor Blacks over Whites partly for reasons of impression management. Liberals are more motivated to avoid appearing prejudiced (Wright et al., 2020; Wright \& Esses, 2017) and have stronger beliefs in norms of political correctness (Andary-Brophy, 2015; Strauss \& McGrath, 2016).

Additionally, racial sympathizers consistently showed negative attitudes toward Whites regardless of whether these Whites were rich, poor, and/or Christian. The pro-Black/anti-White bias assessed in the symbolic racism scale is approximately three times larger than the antiBlack/pro-White bias picked up by the scale. Not only is the scale largely assessing political conservatism, rather than anti-Black attitudes, it may also be largely assessing anti-White 
attitudes, rather than anti-Black attitudes. The scale appears to be measuring substantial content for which it was not designed to measure.

\section{Conclusion}

Thirty-five years ago Sniderman and Tetlock (1986b) suggested "It is a mistake to leech away the meaning of racism, to diminish it, by making it merely a synonym for political attitudes with which one happens to disagree" (p. 186). This is still poignant today. After over 40 years of research on symbolic racism, scholars are still debating what the construct measures and, unfortunately, symbolic racism scales have become a staple in the psychology and political science literatures (Biernat \& Crandall, 1999; Carney \& Enos, 2017), despite measurement problems. Symbolic racism is typically interpreted as a measure of racism, despite how little anti-Black affect appears to be expressed through the scale. Thus, we concur with Carmines et al. (2011) that the commonly used symbolic racism measure "is not a valid measure of racial prejudice and, therefore, does not provide relevant, much less convincing, evidence about the extent to which racial animosity continues to dominate the thinking of white Americans" (p. 100). We suggest a simple corrective course of action. Scholars should think more critically about using the symbolic racism scale as a measure of anti-Black affect. When interpreting literature in which the scale is used, scholars should think more critically about the interpretation of the presented data. Sears and Henry (2005) state, "these controversies are of more than mere academic consequence" (p. 101). Racism in the United States, especially anti-Black racism, is its longest running social problem. But how can social scientists contribute to solving this problem if our scales do not measure what we intend to measure? 


\section{References:}

Abramowitz, A., \& McCoy, J. (2019). United States: Racial resentment, negative partisanship, and polarization in Trump's America. The ANNALS of the American Academy of Political and Social Science, 681(1), 137-156. https://doi.org/10.1177/0002716218811309

al Gharbi, M. (2018). Race and the race for the White House: On social research in the age of Trump. The American Sociologist, 49(4), 496-519. https://doi.org/10.1007/s12108-0189373-5

Allport, G. W. (1958). The nature of prejudice. Garden City, NY: Doubleday Anchor Books. Andary-Brophy, C. A. (2015). Political correctness: Social-fiscal liberalism and left-wing authoritarianism (Unpublished M.A. Thesis). University of Toronto.

Biernat, M., \& Crandall, C. S. (1999). Racial attitudes. In Measures of Social Psychological Attitudes, Vol. 2. Measures of political attitudes. (pp. 297-411). San Diego, CA, US: Academic Press.

Bobo, L.D., \& Johnson, D. (2004). A taste for punishment. Du Bois Review, 1(1), 151-180.

Brewer, M. B. (1999). The psychology of prejudice: Ingroup love and outgroup hate? The Journal of Social Issues, 55(3), 429-444. https://doi.org/10.1111/0022-4537.00126

Carney, R. K., \& Enos, R. D. (2017). Conservatism and fairness in contemporary politics: Unpacking the psychological underpinnings of modern racism. Presented at the 2017 NYU CESS Experiments Conference.

Chambers, J. R., Schlenker, B. R., \& Collisson, B. (2013). Ideology and prejudice: The role of value conflicts. Psychological Science, 24(2), 140-149. https://doi.org/10.1177/0956797612447820 
Cooper, C. A., \& Knotts, H. G. (2006). Region, race, and support for the South Carolina Confederate flag. Social Science Quarterly, 87(1), 142-154. https://doi.org/10.1111/j.0038-4941.2006.00373.x

Craemer, T. (2009). Psychological 'self-other overlap' and support for slavery reparations. Social Science Research, 38(3), 668-680. https://doi.org/10.1016/j.ssresearch.2009.03.006

Ditonto, T. (2020). The mediating role of information search in the relationship between prejudice and voting behavior. Political Psychology, 41(1), 71-88.

Ditonto, T. M., Lau, R.R., \& Sears, D.O. (2013). AMPing racial attitudes: Comparing the power of explicit and implicit racism measures in 2008. Political Psychology, 34(4), 487-510. https://doi.org/10.1111/pops.12013

Feldman, S., \& Huddy, L. (2005). Racial Resentment and White Opposition to Race-Conscious Programs: Principles or Prejudice? American Journal of Political Science, 49(1), 168183. https://doi.org/10.2307/3647720

Graham, J., Haidt, J., \& Nosek, B. A. (2009). Liberals and conservatives rely on different sets of moral foundations. Journal of Personality and Social Psychology, 96(5), 1029-1046. https://doi.org/10.1037/a0015141

Henry, P. J., \& Sears, D. O. (2002). The symbolic racism 2000 scale. Political Psychology, 23(2), 253-283. https://doi.org/10.1111/0162-895X.00281

Hooghe, M., \& Dassonneville, R. (2018). Explaining the Trump Vote: The Effect of Racist Resentment and Anti-Immigrant Sentiments. PS: Political Science\& Politics, 51(3), 528 534. https://doi.org/10.1017/S1049096518000367 
Huang, J., Jacoby, S., Strickland, M., \& Lai, K. K. R. (2016, November 8). Election 2016: Exit Polls. The New York Times. Retrieved from https://www.nytimes.com/interactive/2016/11/08/us/politics/election-exit-polls.html

Kinder, D. R. \& Sanders, L. M. (1996). Divided by color: Racial politics and democratic ideals. University of Chicago Press.

Kinder, D. R., \& Sears, D. O. (1981). Prejudice and politics: Symbolic racism versus racial threats to the good life. Journal of Personality and Social Psychology, 40(3), 414-431. https://doi.org/10.1037/0022-3514.40.3.414

Litman, L., Robinson, J., \& Abberbock, T. (2017). TurkPrime.com: A versatile crowdsourcing data acquisition platform for the behavioral sciences. Behavior Research Methods, 49(2), 433-442. https://doi.org/10.3758/s13428-016-0727-z

Ma, D.S., Correll, J., \& Wittenbrink, B. (2015). The Chicago face database: A free stimulus set of faces and norming data. Behavioral Research Methods, 47(4), 1122-1135. https://doi.org/10.3758/s13428-014-0532-5

Matsueda, R. L., \& Drakulich, K. (2009). Perceptions of criminal injustice, symbolic racism, and racial politics. The Annals of the American Academy of Political and Social Science, 623(1), 163-178.

Maxwell, A., \& Shields, T. (2014). The fate of Obamacare: Racial resentment, ethnocentrism and attitudes about healthcare reform. Race and Social Problems, 6(4), 293-304. https://doi.org/10.1007/s12552-014-9130-5 
McConahay, J. B. (1983). Modern racism and modern discrimination: The effects of race, racial attitudes, and context on simulated hiring decisions. Personality and Social Psychology Bulletin, 9(4), 551-558. https://doi.org/10.1177/0146167283094004

McConahay, J. B. (1986). Modern racism, ambivalence, and the modern racism scale. In J. F. Dovidio \& S. L. Gaertner (Eds.), Prejudice, discrimination, and racism (pp. 91-125). San Diego, CA: Academic Press.

McConahay, J. B., Hardee, B. B., \& Batts, V. (1981). Has racism declined in America? It depends on who is asking and what is asked. Journal of Conflict Resolution, 25(4), 563579. https://doi.org/10.1177/002200278102500401

McConahay, J. B., \& Hough Jr, J. C. (1976). Symbolic racism. Journal of Social Issues, 32(2), 23-45. https://doi.org/10.1111/j.1540-4560.1976.tb02493.x

McGarty, C. (2001). Social identity theory does not maintain that identification produces bias, and self-categorization theory does not maintain that salience is identification: Two comments on Mummendey, Klink and Brown. The British Journal of Social Psychology, 40, 173-176. https://doi.org/10.1348/014466601164777

Mummendey, Amelie, Klink, A., \& Brown, R. (2001). Nationalism and patriotism: National indentification and out-group rejection. The British Journal of Social Psychology, 40, 159-172. https://doi.org/10.1348/014466601164740

Mummendey, Amélie, Simon, B., Dietze, C., Grünert, M., Haeger, G., Kessler, S., ... Schäferhoff, S. (1992). Categorization is not enough: Intergroup discrimination in negative outcome allocation. Journal of Experimental Social Psychology, 28(2), 125144. https://doi.org/10.1016/0022-1031(92)90035-I

O'Brien, K., Forrest, W., Lynott, D., \& Daly, M. (2013). Racism, gun ownership, and gun 
control: Biased attitudes in US Whites may influence policy decisions. PLoS ONE, 8(10), e77552.

Orey, B. D. (2004). White racial attitudes and support for the Mississippi state flag. American Politics Research, 32(1), 102-116.

Pasek, J., Tahk, A., Lelkes, Y., Krosnick, J. A., Payne, B. K., Akhtar, O., \& Tompson, T. (2009). Determinants of turnout and candidate choice in the 2008 US presidential election: Illuminating the impact of racial prejudice and other considerations. Public Opinion Quarterly, 73(5), 943-994.

Payne, B. K., Krosnick, J. A., Pasek, J., Lelkes, Y., Akhtar, O., \& Tompson, T. (2010). Implicit and explicit prejudice in the 2008 American presidential election. Journal of Experimental Social Psychology, 46(2), 367-374. https://doi.org/10.1016/j.jesp.2009.11.001

Schlenker, B. R., Chambers, J. R., \& Le, B. M. (2012). Conservatives are happier than liberals, but why? Political ideology, personality, and life satisfaction. Journal of Research in Personality, 46(2), 127-146. https://doi.org/10.1016/j.jrp.2011.12.009

Sears, D. O., \& Henry, P. J. (2005). Over thirty years later: A contemporary look at symbolic racism. Advances in Experimental Social Psychology, 37, 95-150. http://dx.doi.org/10.1016/S0065-2601(05)37002-X

Sears, D. O., Van Laar, C., Carrillo, M., \& Kosterman, R. (1997). Is it really racism?: The origins of white Americans' opposition to race-targeted policies. The Public Opinion Quarterly, 61(1), 16-53. https://www.jstor.org/stable/2749510

Sidanius, J., Devereux, E., \& Pratto, F. (1992). A comparison of symbolic racism theory and social dominance theory as explanations for racial policy attitudes. The Journal of Social 
Psychology, 132(3), 377-395.

Sniderman, P. M., Piazza, T., Tetlock, P. E., \& Kendrick, A. (1991). The new racism. American Journal of Political Science, 35(2), 423-447. https://doi.org/10.2307/2111369

Sniderman, P. M., \& Tetlock, P. E. (1986a). Symbolic racism: Problems of motive attribution in political analysis. Journal of Social Issues, 42(2), 129-150.

https://doi.org/10.1111/j.1540-4560.1986.tb00229.x

Sniderman, P. M., \& Tetlock, P. E. (1986b). Reflections on American racism. Journal of Social Issues, 42(2), 173-187. https://doi.org/10.1111/j.1540-4560.1986.tb00231.x

Strauss, K., \& McGrath, S. (2016). Temporary migration, precarious employment and unfree labour relations: Exploring the "continuum of exploitation” in Canada's Temporary Foreign Worker Program. Retrieved from http://www.scopus.com/inward/record.url?eid=2-s2.084957621811\&partnerID=40\&md5=83a8c44e4e4080f27102e05387bb9888

Tajfel, H. (1970). Experiments in intergroup discrimination. Scientific American, 223(5), 96103. https://www.jstor.org/stable/24927662

Tajfel, H., Billig, M. G., Bundy, R. P., \& Flament, C. (1971). Social categorization and intergroup behaviour. European Journal of Social Psychology, 1(2), 149-178. https://doi.org/10.1002/ejsp.2420010202

Tajfel, H., \& Turner, J. C. (1979). An integrative theory of intergroup conflict. In W. G. Austin \& S. Worchel (Eds.), The social psychology of intergroup relations (pp. 33-47). Monterey, CA: Brooks/Cole Publishing Company.

Taylor, D. G., Sheatsley, P. B., \& Greeley, A. M. (1978). Attitudes toward racial integration. Scientific American, 238(6), 42-49. https://www.jstor.org/stable/24955752 
Tesler, Michael. 2012. The spillover of racialization into health care: How President Obama polarized public opinion by racial attitudes and race. American Journal of Political Science, 56(3):690-704.

Tien, C. (2017). The racial gap in voting among women: White women, racial resentment, and support for Trump. New Political Science, 39(4), 651-669. https://doi.org/10.1080/07393148.2017.1378296

Wright, J.D., Cheung, I., \& Esses, V. M. (2020). Is support for Confederate symbols motivated by Southern pride or Racism? Further Distinctions between "Traditionalists" and “Supremacists.” https://doi.org/10.31234/osf.io/pnkmy

Wright, J.D., \& Esses, V. M. (2017). Support for the Confederate battle flag in the Southern United States: Racism or Southern pride? Journal of Social and Political Psychology, 5(1), 224-243. https://doi.org/10.5964/jspp.v5i1.687

Zigerell, L. J. (2015). Distinguishing racism from ideology: A methodological inquiry. Political Research Quarterly, 68(3), 521-536. https://doi.org/10.1177/1065912915586631

Zigerell, L.J. (2019). The yuge effects of racist resentment on support for Donald Trump and...Attitudes about automobile fuel efficiency requirements? https://preprints.apsanet.org/engage/apigateway/apsa/assets/orp/resource/item/5dfc5620cd361a001afed23e/original/the-yugeeffect-of-racist-resentment-on-support-for-donald-trump-and-attitudes-about-automobilefuel-efficiency-requirements.pdf 